\title{
Women Work Protection in a Company Based on Law Number 13 of 2003
}

\author{
Desak Gde Dwi Arini ${ }^{*}$, A A Sagung Laksmi Dewi ${ }^{2}$, Ni Made Puspasutari Ujianti ${ }^{3}$ \\ Universitas Warmadewa, Denpasar, Bali ${ }^{1,2,3}$ \\ $\left\{\right.$ desakgdedwiarini@gmail.com $\left.{ }^{1}\right\}$
}

\begin{abstract}
The development of modern society has forced women to increasingly participate in various activities, including productive work. For many years, there have been cases of infringement of women's rights and various challenges at work. The aim of this present study is to determine the women's work protection in a company reviewed from Law No. 13 of 2003 that has aim to determine the constraints and obstacles faced by women workers in a company. The study uses a normative legal research, which involves reviewing and analyzing laws and regulations, sssessing literature and analyzing applicable laws and regulations. The results showed that the protection of women's work is quite good and runs according to the existing legal rules. The obstacles faced by female workers in a company include natural challenges such as menstruation, pregnancy, and childbirth. Therefore, articles 81 to article 83 of Law Number 13 Year 2003 made provision for leave.
\end{abstract}

Keywords: Work Protection; Women, Companies; Law Number 13 of 2003

\section{Introduction}

In the history of Indonesia, women have been present in various roles and activities, all of which have inspired their successors to further increase their potential in the future. Thus, the advancement of world development, women get the same position and rank as men.

The existence of a man or woman is natural that cannot be avoided and arises when humans are born. Human nature as a man or woman is to create a balance in human welfare itself. But in fact, we often encounter polemics that are fundamental to differences in gender. Various forms of injustice are experienced and felt by women because of their female status.

The traditions and culture of the community and their development also have an effect. The Javanese expression which states, "Perempuan kuwi kanca wingking", shows the meaning of the position of women who are shackled. This means that women do not have the opportunity to develop themselves and women are complementary and have no power at all.

Along with the advancement of technology and industry in this globalization era, it has opened women's eyes and insights, so that many women feel the need to hone themselves so that their potential can develop. With the transition from the industrial era to an era of increasingly rapid information transformation, which finally entered the free market era which 
is a manifestation of globalization, unwittingly has demanded women to fight for their existence more.

Work that are currently developing are jobs that are mostly carried out by men in general, but it does not rule out the possibility for women to do so. This difference is a reflection of the fact that men and women must complement each other in achieving perfection or a higher level of humanity.

Based on a psychological review, there are three sources that stimulate the development of independence of Indonesian women, namely as a consequence of being raised in an economic condition of a family that is deprived, as a manifestation of traditions and social systems that encourage the independence of women as members of society, and as a consequence of educational background and experience of women (Sadli, 2001).

This shows that the development of modern society has forced women to increasingly play a role in various kinds of busy and productive work activities outside the nature of accompanying men. Currently a woman not only acts as a housewife but also a person who helps earn a living. In addition, women in development in all fields also play a role both as citizens and as human resources for development. That way, both women and men have the same rights, obligations and opportunities.

As emphasized in GBHN (Garis-Garis Besar Haluan Negara) regarding the role of women and national development, among others, the position and role of women in the life of the nation and state can be enhanced through national policies carried out by institutions capable of fighting for the realization of equality and justice. gender; and the quality of women's roles and independence can be enhanced by maintaining the value of unity and integrity as well as the historical value of women's struggles, in the context of continuing to empower women and the welfare of families and communities.

Even though the description above states that women and men have equal opportunities in development in all fields, there is still a difference between men and women. These differences include physical and biological aspects. The physical difference is the size and strength of the body, while the biological difference is that women experience menstruation, pregnancy, menopause and men do not experience it (Suma'mur, 2005).

Therefore, specific law regarding female workers requiring protection are stipulated in Law Number 13 of 2003 concerning Manpower, particularly in articles 81 to 83. The Manpower Act applies restrictions on work performed by female workers with consideration that the woman is weak in body to maintain her health and morality.

Similar research conducted by Anasari, Darnela, \& Iswantoro (2016) resulted that the provision of 3 months maternity leave and equal pay between male and female workers for the same work had been fulfilled. However, the right to menstrual leave, the right to receive breastfeeding time, the right to nutritious food and drinks, the provision of shuttle transportation are the rights of women workers that have not been granted. Prajnaparamita (2019), Tumewan (2017), and Sari, Budiartha, \& Arini (2020) reveal that the protection of female workers is regulated in the Decree of the Minister of Manpower Article 76 and also in the Indonesian Transmigration No.Kep 224 / Men / 2003. In addition, Gita, Oleary, \& Seputra (2020) the form of accountability given by the Cafe to the Waitress only provides supplies of first aid kits and compensation money in the event of a work accident.

From this background, examining the protection of women's work in a company in terms of Law Number 13 of 2003 and the obstacles faced by female workers in a company are two aims of this study. 


\section{Method}

This research uses normative legal research type. Normative legal research is carried out by reviewing the literature and analyzing applicable laws and regulations. Literature review is called library research. In addition, this study also uses two problem approaches to solve the problems found, namely the statutory approach and the conceptual approach. This approach looks at the applicable legal rules and the extent to which legal rules are applied, especially to the legal protection of used car showroom consumers in purchasing cars that are not in accordance with the conditions stated in the advertisement. Sources of legal materials used are primary and secondary legal materials. Primary legal materials are obtained from the Civil Code and Law Number 13 of 2003 concerning Manpower. Meanwhile, secondary legal materials are obtained from literature, books, journals and applicable laws and regulations.

\section{Results and Discussion}

\subsection{Protection of Women's Work in a Company in terms of Law Number 13 of 2003}

The provisions in an agreement legally made by the parties shall apply as special law which binds the parties who agree to it (Lex specialis). So, the emphasis on the validity of an agreement is very important as a condition to be able to bind the parties.

The result of not fulfilling the obligations arising from the agreement will make the party who broke the promise can be declared in default. This can cause the injured party to demand compensation through the court.

A valid agreement is an agreement where the requirements therein have been fulfilled in accordance with the Civil Code Article 1320. There are four conditions that must be fulfilled in an agreement, namely mutual agreement to bind himself, an agreement made competently, focus on something or object, and a cause (causal) that is lawful.

This provision is also contained in article 52 paragraph (1) of Law of the Republic of Indonesia Number 13 of 2003 concerning manpower which stipulates that employment agreements for women workers are based on the agreement of the two parties, the ability or ability to take legal actions, the existence of the work that was agreed upon, and the work that was agreed upon must not conflict with the public interest, morals, and the provisions of the prevailing laws and regulations. Tanjung \& Astariyani (2015) concluded that legal protection of the careers women stipulated on Law no 13 of 2013 article 82 (1), article 76 (2), article 83 about labour.

Husni (2004) explains that the intent of these articles are:

a. Agreement of the two parties

The agreement between the two parties, which is commonly referred to as an agreement for those who bind themselves, means that the parties who enter into a work agreement must agree, as if on the things that were agreed upon.

b. Competent to make an agreement

Someone who is old enough is considered competent in making agreements. According to the labor law article 1 number 26 law number 13 of 2003, the age limit in question is at least 18 years old. Besides, that person was not mentally disturbed.

c. Focus on something or object

The promised work is the object of the work agreement between the worker and the employer. The legal consequence of the promised work gives the parties the rights and obligations of a cause that is not against the law. 
The work agreement is valid if the above requirements are met. These requirements are then grouped into two, namely, subjective and objective requirements. The subjective requirement concerns the person making the agreement, while the objective requirement concerns the object of the agreement. The agreement has legal force as long as it has not been canceled by the judge.

The contents of the work agreement are the rights and obligations of workers and companies/entrepreneurs. Labor rights, namely wages. On the other hand, the right of the company/entrepreneur, namely the workforce to do work (Manulang, 1988).

Employment agreements for women workers create a bond on each party. This bond is defined as broader than an agreement. Subekti (1989) said that a bond is an abstract meaning, whereas an agreement is the opposite, a concrete legal event. The work agreement is used as a guideline and evidence for the parties who make it if a dispute occurs between the parties, namely the company and the female worker (Sutedi, 2009).

Preparation or planning is needed to compile a good work agreement. Compiling an agreement by tracing various information from the start to the end of the negotiation and knowing the real interests of the parties will create a good contract (Bintang \& Dahlan, 2000).

As with the conditions, the process of making work agreements for women is done properly and is also very helpful in ensuring the legal certainty of the work agreement made.

The process can be started with the following stages (Djumialdji, 2006):

1) Pre-contract stage

The pre-contract stage is the stage when the parties agree to negotiate/bargain in a negotiation in the form of a memorandum of understanding (MoU).

2) Contract preparation stage

The parties write down the points agreed upon in a contract, either under hand or made in notarial. When drafting a contract/agreement, all aspects contained in an agreement must be covered and made completely. Aspects that have not been regulated in the contract will be discussed deliberately, if later there is a difference in understanding between the parties, then general legal principles contained in the Civil Code Book (KUHPerdata) will be used.

3) Post contract stage

After finishing handling a contract/agreement, the parties must pay attention to the rights and obligations of each party so that one party does not cause losses to the other.

However, the process of making work agreements for women as described above is considered by some to be too long and time-consuming and costly, not to mention that collective labor agreements must involve trade unions, so this method is considered ineffective.

From the results of the company survey with female workers, it is known that in responding to the aforementioned constraints, this company has coped with it by making a work agreement in the form of a standard agreement, namely an agreement signed by both parties in the form of a finished agreement and only to be presented to the candidate. workers without going through the pre-agreement process, this method is felt to be more effective and efficient in terms of time and cost.

In the implementation of development, female workers have an important role and meaning as a supporting element for the success of national development so that it is necessary to work on peace and work health so that what they face in work can be considered as much as possible so that vigilance in carrying out work is guaranteed. Soepomo (1983) divides work protection into three types as described above, namely economic protection, 
social protection, and technical protection. In practice, the work protection applied to women workers can be said to be quite good in accordance with the existing legal regulations, and this is highly expected by the Government in general and employers and workers in particular.

Articles 81 to 83 of Law Number 13 of 2003 prohibit employers from requiring female workers to work on the first and second day of menstruation, as well as providing one and a half months of rest before the time when they are calculated to give birth to children and one and a half months After giving birth to a child/pregnancy loss and this is the case for female workers who still breastfeed their children during working time.

1. Paid leave

Although pain during menstruation can be treated with mild pain barrier drugs, to prevent it from interfering with work activities. However, regulations regarding menstrual leave are still needed as a form of work protection for women workers. In practice, women workers almost never take menstrual leave, even though they are still given full wages. Workers who do not leave are provided with a special room to rest with adequate rest periods, and are given pain barrier drugs. The procedure that must be done to obtain menstrual leave is to fill out the menstrual leave form which is then submitted to the personnel department.

2. Maternity leave

Female workers who take maternity leave in a company are still given full wages up to the birth limit of their second child. And women workers get maternity allowances for those who occupy positions and those who do not occupy positions usually do not receive maternity benefits, this often happens in practice in companies. The procedure for obtaining maternity and childbirth leave is to apply for leave through filling out forms for maternity and maternity leave, accompanied by a doctor's or midwife's certificate, photocopy of marriage certificate, photocopy of husband's ID card, and copy of family card.

3. Breastfeeding

A company still gives permission to female workers to breastfeed their children during work breaks. And in fact none of the women workers ask permission to breastfeed during working hours, but they do ask for permission to go home during work breaks and come back again when the break ends.

\subsection{Constraints and Obstacles Faced by Female Workers in a Company}

With the nature of women as physically weak creatures compared to men where at certain times they experience natural things such as menstruation, pregnancy and childbirth, prompting the enactment of articles 81 to article 63 of the Law of the Republic of Indonesia Number 13 of 2003 which manifested in the form of leave.

In the application of menstrual leave, the obstacle faced is the reluctance of the female workers concerned to take this menstrual leave, because they consider that menstruation is a common thing experienced by women. So that for them there is no problem if they continue to work during menstruation, and feel that their work activities are not disturbed. Ramaputra, Budiartha, \& Seputra (2020) stated that the less than optimal performance of workers working on an item and the lack of labor they currently have is an inhibiting factor.

Maternity leave provided by a company is one month before delivery and one month after delivery. Meanwhile, the Manpower Act stipulates that maternity and maternity leave is one and a half months before giving birth and one and a half months after giving birth. This, too, is an obstacle to implementing the provisions regarding maternity and maternity leave according to article 82 of Law Number 13 of 2003 concerning manpower. For female workers who are 
still breastfeeding their children, the company does not provide a special place for day care for their children and there is no proper opportunity to breastfeed their children during working time. This is also supported by the fact that in general before leaving for work, they breastfeed their children first and ask permission to go home during work breaks, to return to breastfeeding their children. They can go home at recess of approximately two hours. This is also an obstacle for companies to implement article 83 of the Law of the Republic of Indonesia No.13 of 2003.

The presence and work ethic of women workers makes articles 81 to 83 of Law Number 13 of 2003 not fully applicable in a company, and it still requires a separate policy from the employer with an agreement made with the female workers' representatives.

In overcoming these obstacles, the company makes every effort to realize the essence of articles 81 to 83 of Law Number 13 of 2003 concerning menstrual leave, maternity leave and childbirth and breastfeeding, by providing certain policies which are enforced after deliberation. between the company and the female worker representatives first. It is the responsibility of the Government, in this case the Department of Manpower, to pay attention to the fate of female workers.

This attention can be done by providing direct counseling to female workers in a company about the importance of occupational health, especially for pregnant women as a priority. All of these efforts are carried out for the proper and effective implementation of articles 81 to 83 of Law Number 13 of 2003, so that there are no problems regarding the special rights of women workers that have never been owned by men.

With the above described matters. Then it is clear what are the rights and obligations of the parties who have agreed on the work. In addition, based on the work agreement, it will create a working relationship that automatically brings consequences in the form of rights and obligations for both parties. Denial of things that have been promised will bring consequences that have been mutually agreed in the working relationship. In general, violations that usually occur in work relationships can be caused by (Sidabutar, 2007).

1) Behavior and or actions of employers towards employees

2) Behavior and or actions of employees towards employers

From the survey results that the legal consequences in the form of sanctions that will be imposed on employees who commit violations, this has been confirmed in Law Number 13 of 2003 that the work agreement for a specified period reads: If the employer or worker terminates the work agreement for a certain time before the time expires, then the party terminating the work agreement is obliged to pay compensation to the other party in the amount of the workers' remaining wages until the time or the worker should be finished, unless the employment relationship is terminated for reasons of forcing/serious errors of the worker. All disputes arising from this work agreement will be resolved by deliberation and consensus, and if they cannot be resolved, the parties will resolve them through the Registrar's Office of the Denpasar District Court.

\section{Conclusion}

Starting from the results of the research above, it can be concluded that this research is as follows:

1. Protection of women's work in a company in terms of Law Number 13 of 2003 concerning Manpower, in practice it can be said that it runs quite well in accordance with existing legal regulations. The regulation regarding the protection of women's work 
requires a good relationship between employers and the Ministry of Manpower to avoid the possibility of arbitrary actions by employers against female workers.

2. Constraints and obstacles faced by female workers in a company are menstruation, pregnancy, and childbirth, thus encouraging the enactment of articles 81 to 83 of Law Number 13 of 2003 which are manifested in the form of leave. In overcoming these obstacles and obstacles, the company makes every effort to realize this article by providing certain policies.

\section{References}

[1] Anasari, F., Darnela, L., \& Iswantoro. (2016). Pelaksanaan Perlindungan Hukum Pekerja Perempuan Berdasarkan Undang-Undang Nomor 13 Tahun 2003 tentang Ketenagakerjaan (Studi Kasus di CV. Sinar Joyo Boyo Plastik, Kota Magelang). Universitas Islam Negeri Sunan Kalijaga Yogyakarta.

[2] Bintang, S., \& Dahlan. (2000). Pokok-pokok Hukum Ekonomi dan Bisnis. Bandung: PT. Citra Aditya Bakti.

[3] Djumialdji, F. (2006). Perjanjian Kerja (2nd ed.). Jakarta: Sinar Grafika.

[4] Gita, I. B. A. S., Oleary, N. H., \& Seputra, I. P. G. (2020). Perlindungan Hukum terhadap Waitress di Cafe Katulebo berdasarkan Undang-Undang Nomor 13 tahun 2003 tentang Ketenagakerjaan. Jurnal Preferensi Hukum, 1(1), 222-227.

[5] Husni, L. (2004). Penyelesaian Perselisihan Hubungan Industrial Melalui Pengadilan dan Di Luar Pengadilan. Jakarta: PT. Raja Grafindo Persada.

[6] Manulang, S. (1988). Hukum Ketenagakerjaan di Indonesia. Jakarta: PT. Rineka Cipta.

[7] Prajnaparamita, K. (2019). Perlindungan Hukum Terhadap Tenaga Kerja Wanita Di Indomaret Kota Pekanbaru Berdasarkan Undang-Undang Nomor 13 Tahun 2003 Tentang Ketenagakerjaan. Adminitrative Law \& Governance Journal, 2(1), 34-46.

[8] Ramaputra, N. A., Budiartha, I. N. P., \& Seputra, I. P. G. (2020). Perlindungan Hukum Terhadap Pekerja yang Melebihi Batas Waktu Kerja di PT. Adi Putra Denpasar. Jurnal Analogi Hukum, 2(2), 240-245.

[9] Sadli, S. (2001). Kemandirian Perempuan Tinjauan Psikologi. Kelompok Studi Wanita Puslit.

[10] Sari, N. P. N. E., Budiartha, I. N. P., \& Arini, D. G. D. (2020). Perlindungan Hukum terhadap Pekerja dalam Perjanjian Kerja Waktu Tertentu Menurut Undang-Undang no 13 Tahun 2003. Jurnal Analogi Hukum, 2(1), 124-128. https://doi.org/10.22225/ah.2.1.1613.124-128

[11] Sidabutar. (2007). Pedoman Penyelesaian PHK. Banten: Express.

[12] Soepomo, I. (1983). Hukum Perburuhan Bidang Hubungan Kerja. Jakarta: Djambatan.

[13] Subekti. (1989). Pokok-Pokok Hukum Perdata. Jakarta: PT. Intermasa.

[14] Suma'mur. (2005). Hygiene Perusahaan dan Kesehatan Kerja. Jakarta: Gunung Agung.

[15] Sutedi, A. (2009). Hukum Perburuhan. Jakarta: Sinar Grafika.

[16] Tanjung, N. P. P., \& Astariyani, N. L. G. (2015). Perlindungan Hukum Pekerja Wanita terhadap Hak Reproduktif. Kertha Semaya, 3(3), 147-173. Retrieved from https://ojs.unud.ac.id/index.php/kerthasemaya/article/view/13173

[17] Tumewan, W. I. (2017). Perlindungan Hukum terhadap Pekerja Perempuan di Malam 
Hari berdasarkan Undang-Undang Nomor 13 Tahun 2003. Lex Privatum, V(4). https://doi.org/10.1017/CBO9781107415324.004 